\title{
Inclusion of mental health in primary health care: care strategy in the territory
}

\author{
Inclusão da saúde mental na atenção básica à saúde: estratégia de cuidado no território \\ Inclusión de la salud mental en la atención primaria de salud: una estrategia de cuidado en el territorio
}

'Universidade Federal Fluminense. Niterói, Rio de Janeiro, Brazil.

"Escola Nacional de Saúde Pública Sergio Arouca.

Rio de Janeiro, Rio de Janeiro, Brazil.

How to cite this article:

Souza AC, Amarante PD, Abrahão AL. Inclusion of mental health in primary health care: care strategy in the territory. Rev Bras Enferm. 2019;72(6):1677-83. doi: http://dx.doi.org/10.1590/0034-7167-2018-0806

Corresponding Author:

Ândrea Cardoso de Souza

E-mail: andriacsouza@gmail.com

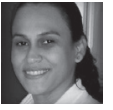

Submission: 10-29-2018 Approval: 04-11-2019

\begin{abstract}
Objective: To analyze the strategies, challenges and possibilities of the articulation between mental health and primary health care from the perspective of health managers. Method: Exploratory, qualitative research carried out with 28 managers of mental health and primary care. The data were collected through semi-structured interviews between July and November 2013 and submitted to thematic content analysis. Results: The inclusion of mental health actions in primary care made it possible, in the view of managers, to increase users' access to the care they need. This care strategy allows the extension of care practices in the territory, with matrix support as the main tool for the implementation of this care strategy. Final considerations: The articulation between primary care and mental health is a powerful device for psychosocial care, but it demands a new conformation of the Psychosocial Care Centers (Caps) and primary care services.

Descriptors: Mental Health; Primary Health Care; comprehensive Health Care; Deinstitutionalization; Nursing.
\end{abstract}

\section{RESUMO}

Objetivo: analisar as estratégias, desafios e possibilidades da articulação entre a saúde mental e a atenção básica à saúde a partir da perspectiva de gestores da saúde. Método: pesquisa exploratória, qualitativa, realizada com 28 gestores de saúde mental e atenção básica. Os dados foram coletados por meio de entrevistas semiestruturadas, entre julho e novembro de 2013, e submetidos à análise de conteúdo temática. Resultados: a inclusão das ações de saúde mental na atenção básica possibilitou, na visão dos gestores, a ampliação do acesso dos usuários aos cuidados de que necessitam. Esta estratégia de atenção possibilita extensão das práticas de cuidado no território, tendo o apoio matricial como a principal ferramenta para a implementação dessa estratégia de cuidado. Considerações finais: a articulação entre a atenção básica e a saúde mental é um dispositivo potente para a atenção psicossocial, porém, demanda uma nova conformação dos Centros de Atenção Psicossocial (Caps) e dos serviços da atenção básica.

Descritores: Saúde Mental; Atenção Primária à Saúde; Integralidade em Saúde; Desinstitucionalização; Enfermagem.

\section{RESUMEN}

Objetivo: analizar las estrategias, los desafíos y las posibilidades de articulación entre la salud mental y la atención primaria de salud desde la perspectiva de los gestores de la salud. Método: investigación exploratoria y cualitativa, realizada con 28 gestores de salud mental y de la atención primaria. En la recopilación de datos se utilizaron entrevistas semiestructuradas, realizadas en el período entre julio y noviembre de 2013 , las cuales se sometieron al análisis de contenido temático. Resultados: desde la perspectiva de los gestores, la inclusión de las acciones de salud mental en la atención primaria permitió que los usuarios amplíen el acceso al cuidado que necesitan. Esta estrategia de atención permite difundir las prácticas de cuidado en el territorio, y cuenta con un apoyo central como la principal herramienta para implementar esta estrategia de cuidado. Consideraciones finales: la articulación entre la atención primaria y la salud mental es un mecanismo clave en la atención psicosocial, sin embargo, demanda una nueva conformación de los Centros de Atención Psicosocial (Caps) y de los servicios de la atención básica.

Descriptores: Salud Mental; Atención Primaria de Salud; Integralidad en Salud; Desinstitucionalización; Enfermería. 


\section{INTRODUCTION}

In Brazil, the reorientation of the traditional health care model which is related to the adoption of practices based on the premise of welcoming users ${ }^{(1)}-$ is anchored in primary care as a strategy for ordering health services, systems and practices ${ }^{(2)}$. Thus, this becomes the strategic point for restructuring the Unified Health System (SUS), constituting one of the entry doors closest to the people, capable of integrating the principles that govern the system.

In mental health, with the advent of the process of Psychiatric Reform, the recommendations of the national public policy for reorienting the attention model emphasize the territory ${ }^{(3)}$ as a privileged locus of care. In addition, they advocate the implementation of substitutive services to the asylum model, such as the Psychosocial Care Centers (Caps) and the Residential Therapeutic Services (SRT), and greater interlocution with community devices which, oriented towards the rescue of citizenship and valorization of subjects' autonomy, aim at universal, integral and qualified access to users of mental health services ${ }^{(4)}$.

The inclusion of mental health actions in primary health care (PHC) is a public policy that, in addition to being a strategy to cause ruptures in the traditional model of care and advances in the field of mental health, aims to expand the psychosocial care clini $^{(5-7)}$. To do so, it is necessary to qualify PHC teams for psychosocial care, and one of the devices for implementing this strategy is matrix support. This aims to offer support in specific areas and enable exchanges of knowledge to share situations with the local health team, favoring co-accountability for care.

Mental health problems are one of the major causes of the global burden of disease, and depression, anxiety and drug use are among the leading causes of disability worldwide ${ }^{(8)}$. The burden of mental disorders continues to grow, with significant impacts on population health, accounting for almost $13 \%$ of the global burden of disease ${ }^{(9)}$, with estimates of increase over the next decade. This scenario is largely due to lack of resources, low budget for mental health in low and middle income countries, underutilization of services, and stigma associated with mental illness ${ }^{(10)}$.

Given the context, mental health has become a matter of concern and agenda among health managers, whose issues need to be treated with the urgency they deserve, and require increasing investments in the territorial services for the development of care actions. This fact is a warning sign and requires that new approaches to mental health be designed, and the inclusion of mental health actions in $\mathrm{PHC}$ is a more accessible possibility of care that aggregates important characteristics of psychosocial care.

The expansion of community mental health services has been a subject of constant debate among managers, practitioners and public policymakers in the area, and it is important to consider that services need to reflect users' priorities, be mobile and be close to people's homes. Moreover, treatment should be based on unique therapeutic projects.

\section{OBJECTIVE}

To analyze the strategies, challenges and possibilities of the articulation between mental health and primary health care from the perspective of health managers.

\section{METHOD}

\section{Ethical aspects}

The research project was submitted to the Research Ethics Committee of the Sérgio Arouca National School of Public Health of the Oswaldo Cruz Foundation (ENSP/FIOCRUZ), and was approved in May 2011. All of the recommendations of Resolution 466 of December 12, 2012 of the National Health Council (CNS) were followed. All of the participants were briefed about the risks in the research and signed the Free and Informed Consent Form.

\section{Study design}

This is an exploratory, cross-sectional study with a qualitative approach.

\section{Methodological procedures}

We used semi-structured interviews with questions on the history of the articulation between mental health and primary health care, its functioning, the ways of working in the territory, its challenges and possibilities.

\section{Scenario of the study}

All the 13 Caps of the city of Rio de Janeiro constituted the scenarios of the study, 10 of them of type II and three of type III which differ primarily as regards population size, Caps II predicted for municipalities with 70,000 and 200,000 people and Caps III for municipalities with a population over 200,000 people. A second difference lies in days and shifts. While Caps II can run on up to three shifts on weekdays, Caps III runs 24 hours a day, including holidays and weekends - spread across four planning areas, plus 13 Basic Health Units (BHUs) indicated by Caps. To include BHUs, the following criteria were considered: attending to mental health users, be located in the same territory of action, and developing work articulated with the Caps.

\section{Sample}

Research participants were two representatives of the municipal health management and 26 managers linked to the Caps and BHU studied.

The selection of participants was conceived so as to capture the reality of the implementation of mental health actions in primary care in the city of Rio de Janeiro. It was believed that these participants could help in the design of implementation strategies, as well as delineate the main impasses and challenges and present the results of this modality of attention at both the macropolitical and micropolitical levels of care.

\section{Production and organization of data}

Data collection was done through semi-structured interviews performed individually at the participants' workplace, with average duration of 45 minutes each. They were recorded on an 
audio device and transcribed in full. Data collection took place from July to November 2013.

Primary care professionals are identified by the letters " $P C^{\prime}$, Psychosocial Care Centers by the acronym "Caps", followed by a numeral corresponding to the chronological order of the interviews, and municipal managers by the letter " $\mathrm{M}$ ", also followed by a number, according to chronological order of execution.

The data were organized into five thematic categories, called axes-tools: Mental health in primary care: a proposal for integrality; Mental health in primary care: a possibility of equity in care; Mental health practices in primary care: device for access to health; Territory as a privileged space for mental health in primary care; and Networking: a booster of mental health practices in primary care.

\section{Data analysis}

The data were submitted to analysis of thematic content ${ }^{(11)}$, a process that allowed the production of inferences about the reality of services and a better apprehension of the process of inclusion of mental health actions in the primary care services in the city of Rio de Janeiro.

The categorical system based on the theoretical framework consisted of five units of analysis, considered as axes-tools for operating the inclusion of mental health practices in primary health care, namely: integrality, equity, access, territory and network.

\section{RESULTS}

The study had the participation of 28 regional health managers in the municipal scope of Rio de Janeiro, aged between 25 and 66 years, all of them with complete higher education: eight nurses, eight psychologists, four occupational therapists, three physicians, two social workers, two speech therapists and one nutritionist.

\section{Mental health in primary care: a proposal for integrality}

Integrality materializes insofar as welcoming, bonding and accountability allow an approximation between the actors involved, and these discuss and produce new possibilities of life, new paths, new capabilities, skills.

With the arrival of the Family Health Strategy, we are managing to get closer to primary care. When there is a case that we think should be discussed with the polyclinic, with the Health Center, we call the professionals of that unit right away to discuss it, and this partnership is not only with Health, but also with the Secretariat of Social Development, with Education, we are striving to enter all areas. (Caps 8)

Integrality materializes in the daily life of services as the links between users and professionals are maintained longitudinally.

Several users who are now followed up in primary care maintain the bond of friendship with the team and other Caps users and therefore attend some workshops, such as football, take part in parties, outings, etc. (Caps 1)

\section{Mental health in primary care: a possibility of equity in care}

Insanity brings with it a history of stigma and this makes those considered insane to be treated in a way where equity is difficult to materialize.

Mental health is not something apart from people's lives, even patients who have mental health problems also have problems of hypertension, diabetes, other problems in life, and not to separate mental health from these patients' life context is one of our main goals, when we direct this patient to primary care. (G2)

\section{Mental health practices in primary care: device for access to health}

One of the challenges posed today for implementing comprehensive mental health care in the experience studied is directly related to the issue of accessibility of territorial care. To ensure access to mental health care, services need to be available to the population that needs it. That is why services need to be close to people's living places.

Expanding access consists primarily in taking off those patients who are but should not be in specialized mental health services, and then I open vacancies for those who really should be being conducted, along with primary care for mental health. (G2)

In order for users to have access to the health services they need, a network of services with different levels of complexity should be available, one that allows them to enter at the point of the network they can access.

In the health network in general, access has been very difficult for our clientele, we have a Ready Care Unit [UPA] here on our side, for a long time we could not access it, we had to accompany the patients so that they could be attended to, we talk about it in meetings and even with the other institutions. And they say that the team is not prepared to receive psychiatric patients, that they do not know how to speak. (Caps 3)

Today we have had a strong expansion of access, both for mental health and the other components of care, with the expansion of primary care, but the Caps network is very timid and modest, there are few Caps in the city. (G2)

\section{Territory as a privileged space for mental health in pri- mary care}

The practices of mental health care are increasingly focused on the territorial axis and are enhanced through articulation with primary care.

Community agents and the Family Health Strategy help us in the clinical part, not necessarily in mental health, but also in the other part regarding the territory, housing and other aspects that make up the subject's health. So I think this multiprofessional work is fundamental to take care of this territory's health, because it is very vulnerable. We have partners all the time, in cases of violence, in cases of childhood and adolescence, in cases that sometimes have no space for care, so, in this, we keep establishing other territories. (Caps 6) 
This experience demonstrates that activities performed by non-specialized devices extend the spaces of care and contribute to the demystification of insanity.

Handicraft, sewing, mosaic workshops are held in the community, they are meant for the entire population, we experience cases of users who could not reach the Caps but manage to stay in the community workshops, which is quite interesting. (Caps 4)

The articulation of Caps with ESF has been a possibility of care for users residing in dangerous and violent areas, since Family Health has a marked presence in these territories.

There are dangerous areas where we cannot get in and there are some cases in which we do ask the family health teams to follow up, and then they reach out, and whatever the user needs we try to find a way to get it to him/her. (Caps 1)

\section{Networking: a booster of mental health practices in pri- mary care}

Networking demands broadening the notion of health. Psychosocial care takes place in the interface of the resource and support networks (schools, kindergartens, leisure spaces, possibility of participation in some type of work, better living conditions, etc.). It is essential to expand the concept of health.

We were very focused on the field of mental health, and we need more and more to interact with other fields such as culture, work, and work relations. (Caps 9)

Networking is paramount for the adoption of mental health actions in primary care, and because of its characteristics it has configured itself as an important device for the adoption of new modes of care.

I think that primary care has powerful resources to help Caps move forward in the territory, even by the very strategy of team formation, in partnership with the community health agent, who is a person who knows the territory well. (Caps 5)

In order for inclusion of mental health actions in primary health care to be an effective device - through the establishment of a network of resources and support - it is necessary to develop permanent education actions and to qualify health professionals for an attentive and careful listening of the other's suffering; otherwise, it will be difficult to imagine primary care being effective in the field of psychosocial care.

It takes a lot of training, of both the Caps staff and primary care. (Caps 6)

It was evidenced that the fragility of territorial actions proposed by the Caps, developed in the scope of primary care, is pronounced.

There is contact with other health services and other public service sectors, but contacts with the local network are almost non-existent. (Caps 10)
The possibility of building forms of care based on solidarity, autonomy and citizenship of users was found as a facilitator of the inclusion of mental health actions in primary care. This strategy has made it possible to increase user participation in the processes of social exchanges in the city. We identified care technologies materialized through shared home visits and follow-ups, activities such as soccer games, participation in handicraft fairs in the community, and cultural activities, not only for users, whether from primary care or mental health, but for the population.

Another facilitating point is the matrix support that, in the experience researched, constitutes a guideline-tool for implementing mental health actions in primary care. Different configurations of this support have been found: some teams have established a space/time for matrix support, where Caps professionals go to the basic unit to discuss some situations and cases that demand further consideration by other primary attention professionals; sometimes matrix support takes place in a shared service, during a joint home visit; or other arrangements, which were also found. It was noticed that when the matrix support happens, it boosts the assumption of co-responsibility between primary care and Caps teams.

Despite all the potential of the inclusion of mental health actions in primary care, impasses were found. These include the number of professionals with the necessary skills and availability to implement this care strategy, the training still insufficient for this work, management issues, such as the lack of definition of guidelines to be adopted by the services and issues related to financing for expansion of the territorial network in mental health. Some professionals of basic units have argued as reasons for non-implantation of mental health care the precariousness of the service and non-specialized formation of professionals. The issues mentioned by CAP professionals as factors that hinder the inclusion of mental health actions in primary care were: situations that go beyond the restricted scope of health, social vulnerability, and insufficient resources.

It was found that primary care services are not responsible for the care they are required to provide in relation to mental health. Few are the spaces and discussion forums for implementation of a co-accountable work process.

Few are the innovations resulting from this articulation. However, the practices and technologies of care resulting from this articulation are moving towards a more integral and sensitive attention to differences. We have observed experiences that make disruptions and create possibilities of differential care in mental health in the territory. We verified the construction of effective, affective networks, of solidarity and power, among the different resources of the territory, but which still happen in a very incipient way in some areas of the city, where intersectoral work stands as an imperative rather than as an ethical and political demand.

\section{DISCUSSION}

Primary care has potential in the development of mental health actions, being a strategy of demystification of insanity of greater reach than the specialized services ${ }^{(12)}$ due to its greater capillarity in the territory. This articulation, however, still presents itself as a complex and at the same time stimulating challenge for the development of practices and new technologies of care. 
Primary care is a privileged space for a comprehensive, longitudinal follow-up, close to the community, which allows a more complex approach to demands, including mental health ${ }^{(13)}$. Thus, its implementation has been a guideline of public policies in the search for the universality of care and the expansion of access to health services ${ }^{(14)}$.

In order for us to have practices of care rather than of exclusion, it is imperative that services take full care as a prerogative for work, and that they value the subjects in their complexities. Welcoming and bonding are operational prerogatives of comprehensive health practices ${ }^{(15)}$. These concepts are linked to a differentiated practice, which operates in the micropolitics of care, in the relational sphere. These are broad concepts that require changes and organization of the whole system, involving professionals, managers, users and community; which requires a process of constant interaction between those involved, so that care practices are, in fact, produced ${ }^{(16)}$.

The debate on integrality sends us to the field of health micropolitics and its articulations ${ }^{(17)}$ and is a concept linked to different forms of knowledge and practices that interact all the time in everyday life. The inclusion of mental health actions at the primary level of care constitutes a proposal for comprehensive health care that increases the production of care ${ }^{(18)}$.

Equity is part of a historical process of social struggles that are established in different contexts, with a view to the formation of differentiated citizenship patterns ${ }^{(19)}$. It corresponds to an important guiding principle in the definition of health policies and its unfolding in programs and actions. It is related to delivering health care according to the needs of each subject. It considers, therefore, that each subject differs from the other in his/her health demands ${ }^{(12)}$.

Equity is a fundamental guideline for psychosocial care services, since it presupposes considering the uniqueness of subjects facing the process of psychic illness. Therefore, professionals and services need to adopt more flexible practices, as well as to have greater plasticity and porosity to fit the differences in the service space. Working from the perspective of equity, it is possible to adopt inclusive practices in health.

In this sense, the pursuit of equity implies reflecting on aspects of the organization of work microprocesses, management and planning of health actions, and impels the construction of new knowledge and practices. As it is a still difficult principle to achieve in the field of mental health, especially because of the stigma related to people suffering from mental disorders, it is believed that it can be exercised within the articulation between mental health services and primary care. Access to the health services network is a dimension of continuity of care and, for that, requires the existence of an articulated and integrated network for viability of coordinated work, involving the multiple dimensions of daily life, such as housing, work and leisure. The structure of the service, the activities offered and the shifts and ways of functioning may or may not empower users to access health actions and services. For that, it is key that care happens as close as possible to people's lives. And considering that primary care is done closer to people, it is necessary to encourage care in this area of attention, in order to increase access to the services by users who need them ${ }^{(20)}$. However, many are the impasses to be overcome in this direction.
To think that mental health practices should have the territory as a reference means to say that it is necessary to act in it, producing strategies of solidarity, being a reference, transforming the relations of society with insanity. This understanding corroborates breaking with the traditional paradigm of mental health care and prompts the adoption of the multiple dimensions of the clinic. With the expansion of the field of action, the production of changes towards the demystification of insanity is increased. Ensuring a place, a possible space for insanity, for difference to coexist is imperative for the adoption of other ways of caring ${ }^{(7)}$. We need to produce territories that are capable of including subjects instead of segregating them by their differences.

This modality of attention shifts care to the territorial axis, the area on which the service focuses and where responsibility for mental health issues must be taken. This means that a team must act in the spaces and paths that make up people's lives ${ }^{(21)}$, developing, in this perspective, an active role in promoting mental health in the locality ${ }^{(22)}$ and contributing to the reduction of stigma $^{(13)}$, to demystification of madness, and to the process of Psychiatric Reform.

Both mental health services and primary health care provide for a close relationship between health and other sectors of society, because in order to create differentiated practices, they must be integrated as a network of relationships that go beyond health, and work for building social relations in search of a new attitude towards the complexity of the health process ${ }^{(23)}$.

The networks must conform to the different realities, just as they must consider the resources available for their conformation in each locality. The purpose of networking lies in the effectiveness of guaranteeing users' rights to comprehensive and equitable attention.

Structuring other care practices requires the expansion of networks and the use of community social devices, a strategy of care proposed in view of the difficulties faced by mental health services in order to constitute themselves as a device for promoting cultural transformation ${ }^{(24)}$.

This proposal of attention values several dimensions of subjects' lives and constitutes a possibility of including users in new social networks. Networking requires developing new attitudes towards the problems concerning the process of falling mentally ill, allows us to re-dimension the daily praxis of health units and proposes to complexify the approach to health and disease phenomena ${ }^{(25)}$.

Building networks of potency, of life creation, ones that strive for autonomy of the subject and the production of subjectivation is a prerogative of mental health care. Living with the pluralities in the territory is a political exercise. Therefore, this articulation is made between people, ensuring a transit to insanity in the territory and exploiting its potentialities.

\section{Limitations of the study}

One of the limitations of this study is related to the research participants. Only service managers were selected and it was not possible to obtain the perception of users, family and professionals about the inclusion of mental health actions in primary care as a possibility of care. Another limitation is that this study did not include Psychosocial Care Centers for children and adolescents 
(Capsi II) and Psychosocial Care Centers for patients with disorders resulting from drug use and addiction (Caps ad II).

\section{Contributions to the area of nursing, health or public policy}

The contributions of this study are related to the expansion of possibilities and spaces of care in mental health, going from the formal spaces of health units to the streets, to the spaces that make up peoples' lives. Thus, the scope of the actions of health professionals and, consequently, of nurses is widened. Therefore, they need to recognize this articulation as a powerful care strategy for deinstitutionalization and, as a result, for the advancement of the Psychiatric Reform process.

\section{FINAL CONSIDERATIONS}

Integrated actions between primary health care and mental health are fundamental for the construction of processes that result in changes in health service practices, among them matrix support, the main result of this study conducted with managers. The matrix exercise requires a dialogue between professionals in the interprofessional logic and co-responsibility with the construction of collaborative spaces, centered on the integrality of care. The matrix support in the studied municipality converges to the identification that mental health is not totally incorporated in the logic of care of primary health units and that it is necessary to understand that developing mental health practices in primary care is a facilitator of the construction of new possibilities for the psychosocial care clinic.
With this study we learned that: integrality is a working direction for the adoption of mental health practices centered on the subject. Not only integrality in care, but also in the existing community services. As equity struggles to materialize in practice, it is necessary to improve the organization of services to meet the different demands, besides considering the user as a singular person with a right to difference. The adoption of a differential treatment for each individual is still a challenge for care. On the other hand, the inclusion of mental health actions in primary care has allowed, in the view of the managers, the expansion of users' access to the care they need, since it makes it possible to extend care practices. However, one of Caps' main challenges today lies in the extent of its practices and activities in the territory.

Mental health actions in primary care are not restricted to a service. They refer, among other things, to care practices that are networked, based on meetings that result in the taking of responsibility not only by the professionals, but also by a set of devices in service of an attentive and singular care.

Finally, in order to guarantee this proposal of care articulating mental health and primary care, different organizational arrangements are necessary, allowing different ways, such as collective discussion of cases, shared care, joint home visit, supervision by the professional specialist and, noteworthy, modalities that arise from everyday urgencies, such as telephone guidance in situations of social vulnerability. The inclusion of mental health actions in primary care, in this study, was a powerful device for advancing the demystification of insanity and the consolidation of the Psychiatric Reform.

\section{REFERENCES}

1. Coutinho LRP, Barbieri AR, Santos MLM. Acolhimento na Atenção Primária à Saúde: revisão integrativa. Saúde Debate. 2015;39(105):514-24. doi: 10.1590/0103-110420151050002018

2. Fertonani HP, Pires DEP, Biff D, Scherer MDA. The health care model: concepts and challenges for primary health care in Brazil. Ciênc Saúde Colet. 2015;20(6):1869-78. doi: 10.1590/1413-81232015206.13272014

3. Costa LA, Brasil FD. Cidade, territorialidade e redes na política de saúde mental. Cad Ter Ocup UFSCar. 2014;22(2):435-42. doi: 10.4322/ cto.2014.065

4. Pitta AMF. Um balanço da reforma psiquiátrica brasileira: instituições, atores e políticas. Ciênc Saúde Colet. 2011;16(12):4579-89. doi: $10.1590 /$ S1413-81232011001300002

5. Hirdes A, Scarparo HBK. The maze and the minotaur: mental health in primary care. Ciênc Saúde Colet. 2015;20(2):383-93. doi: 10.1590/1413-81232015202.12642013

6. Correia VR, Barros S, Colvero LA. Mental health in primary health care: practices of the family health team. Rev Esc Enferm USP. 2011;45(6):1498-1503. doi: 10.1590/S0080-62342011000600032

7. Yasui S, Luzio CA, Amarante P. Atenção psicossocial e atenção básica: a vida como ela é no território. Rev Polis e Psique. 2018;8(1):173-90. doi: $10.22456 / 2238-152 X .80426$

8. Global Burden of Disease Study 2013 Collaborators. Global, regional, and national incidence, prevalence, and years lived with disability for 301 acute and chronic diseases and injuries in 188 countries, 1990-2013: a systematic analysis for the Global Burden of Disease Study 2013. Lancet. 2015;386(9995):743-800. doi: 10.1016/S0140-6736(15)60692-4

9. Vigo D, Thornicroft G, Atun R. Estimating the true burden of mental illness. Lancet Psychiatry. 2016;3(2):171-8. doi: 10.1016/ S2215-0366(15)00505-2

10. Thyloth $M$, Singh $H$, Subramanian V. Increasing burden of mental illnesses across the globe: current status. Indian J Soc Psychiatry. 2016;32(3):254-6. doi: 10.4103/0971-9962.193208

11. Silva HA, Fossá MIT. Análise de conteúdo: exemplo de aplicação da técnica para análise de dados qualitativos. Qualit@s. 2015;16(1):1-14. doi: 10.18391/qualitas.v16i1.2113 
12. Fagundes Jr HM, Desviat M, Silva PRF. Psychiatric Reform in Rio de Janeiro: the current situation and future perspectives. Ciênc Saúde Colet. 2016;21(5):1449-60. doi: 10.1590/1413-81232015215.00872016

13. Gronholm PC, Henderson C, Deb T, Thornicroft G. Interventions to reduce discrimination and stigma: the state of the art. Soc Psychiatr Psychiatr Epidemiol. 2017;52(3):249-58. doi: 10.1007/s00127-017-1341-.9

14. Silva MVS, Miranda GBN, Andrade MA. Sentidos atribuídos à integralidade: entre o que é preconizado e vivido na equipe multidisciplinar. Interface (Botucatu). 2017;21(62):589-99. doi: 10.1590/1807-57622016.0420

15. Pinheiro R, Silva FH. Pesquisa e práticas de apoio institucional: um ensaio sobre os nexos axiológicos e epistêmicos entre integralidade, humanização e formação na saúde. Saúde Transform Soc [Internet. 2014 [cited 2018 Jul 30];5(2):11-9. Available from: http://pepsic.bvsalud. org/pdf/sts/v5n2/5n2a03.pdf

16. Andrade AB, Bosi MLM. Qualidade do cuidado em dois centros de atenção psicossocial sob o olhar de usuários. Saúde Soc. 2015;24(3):887900. doi: 10.1590/S0104-12902015131949

17. Tanaka OY, Ribeiro EL. Ações de saúde mental na atenção básica: caminho para ampliação da integralidade da atenção. Ciênc Saúde Colet. 2009;14(2):477-86. doi: 10.1590/S1413-81232009000200016

18. Campos RO, Gama CA, Ferrer AL, Santos DVD, Stefanello S, Trapé TL, et al. Saúde mental na atenção primária à saúde: estudo avaliativo em uma grande cidade brasileira. Ciênc Saúde Colet. 2011;16(12):4643-52. doi: 10.1590/S1413-81232011001300013

19. Paim JS. A Constituição Cidadã e os 25 anos do Sistema Único de Saúde (SUS). Cad Saúde Pública. 2013;29(10):1927-53. doi: 10.1590/0102-311X00099513

20. Figueiredo GLA, Martins CHG, Damasceno JL, Castro GG, Mainegra AB, Akerman M. Right to the city, right to health: what are the interconnections? Ciênc Saúde Colet. 2017;22(12):3821-30. doi: 10.1590/1413-812320172212.25202017

21. Furtado JP, Oda WY, Borysow IC, Kapp S. The concept of territory in Mental Health. Cad Saúde Pública. 2016;32(9):e00059116. doi: $10.1590 / 0102-311 \times 00059116$

22. Padmavati R. Community mental health services for the mentally ill: practices and ethics. Int Rev Psychiatry. 2012;24(5):504-10. doi: $10.3109 / 09540261.2012 .712953$

23. Nóbrega MPSS, Domingos AM, Silveira ASA, Santos JC. Weaving the West Psychosocial Care Network of the municipality of São Paulo. Rev Bras Enferm. 2017;70(5):965-72. [Thematic Edition "Good practices and fundamentals of Nursing work in the construction of a democratic society"] doi: 10.1590/0034-7167-2016-0566

24. Almeida IS, Campos GWS. Análise sobre a constituição de uma rede de Saúde Mental em uma cidade de grande porte. Ciênc Saúde Colet [Internet]. 2017 [cited 2017 Dec 30]. Available from: http://www.cienciaesaudecoletiva.com.br/artigos/ analise-sobre-a-constituicao-de-uma-rede-de-saude-mental-em-uma-cidade-de-grande-porte/16458?id=16458

25. Gonçalves DA, Mari JJ, Bower P, Gask L, Dowrick C, Tófoli LF, et al. Brazilian multicentre study of common mental disorders in primary care: rates and related social and demographic factors. Cad Saúde Pública. 2014;30(3):623-32. doi: 10.1590/0102-311X00158412 